\title{
Mid amphibolite facies metamorphism of harzburgites in the Neoproterozoic Cerro Mantiqueiras Ophiolite, southernmost Brazil
}

\author{
LÉO A. HARTMANN and FARID CHEMALE-JÚNIOR \\ Instituto de Geociências, Universidade Federal do Rio Grande do Sul, 91500-000 Porto Alegre, RS, Brazil \\ Manuscript received on July 31, 2002; accepted for publication on January 2, 2003; \\ contributed by LÉO A. HARTMANN*
}

\begin{abstract}
Valuable information is retrieved from the integrated investigation of the field relationships, microstructure and mineral compositions of harzburgites from the Neoproterozoic Cerro Mantiqueiras Ophiolite. This important tectonic marker of the geological evolution of southernmost Brazilian Shield was thoroughly serpentinized during progressive metamorphism, because the oldest mineral assemblage is: olivine + orthopyroxene + tremolite + chlorite + chromite . This $\mathrm{M}_{1}$ was stabilized in mid amphibolite facies $-550-600^{\circ} \mathrm{C}$ as calculated from mineral equilibria. No microstructural (e.g. ductile deformation of olivine or chromite) or compositional (e.g. mantle spinel) remnant of mantle history was identified. A metamorphic event $\mathrm{M}_{2}$ occurred in the low amphibolite facies along $100 \mathrm{~m}$-wide shear zones, followed by intense serpentinization $\left(\mathrm{M}_{3}\right)$ and narrow 1-3 m-wide shear zones $\left(\mathrm{M}_{4}\right)$ containing asbestos.
\end{abstract}

Key words: mineral chemistry, Cerro Mantiqueiras Ophiolite, metamorphism, Neoproterozoic.

\section{INTRODUCTION}

The uncommon presence of ophiolites in the Neoproterozoic geological record of the continents makes these mantle-oceanic crust fragments most significant for the understanding of geotectonic processes active at the end of the Precambrian. The intense alteration of the ophiolites involves deformation in the mantle and in the crust through successive episodes of recrystallization. The result in many cases is an association containing peridotite and amphibolite without remnant, direct evidence of mantle deformation such as strained olivine or chromite. This complex interplay of sequential deformation and recrystallization of the ophiolite requires detailed microstructural investigation of the

Correspondence to: Léo A. Hartmann

E-mail: leo.hartmann@ufrgs.br

*Member of Academia Brasileira de Ciências mineral assemblages and mineral compositions for the unraveling of the processes involved in the emplacement and deformation of the ophiolite.

Neoproterozoic ophiolites occur along extensive sutures in the Arabian-Nubian Shield (Gass et al. 1984, Berhe 1990, Stern 1994) and these have been investigated in much more detail than the coeval ophiolites in the Brazilian Shield. Overall, these ophiolites are remnants of Neoproterozoic ocean basins destroyed during Supercontinent Gondwana amalgamation. All known ophiolites of this age were identified on the basis of the nature of the associated juvenile continental crust, because no direct evidence of mantle deformation has been preserved in the contained minerals. Large gravimetric anomalies suggest the presence of sutures in the Arabian-Nubian Shield (Gass et al. 1984). Brazilian ophiolites are few and small (Suita and Strieder 
1996) and have been as intensely deformed and altered as their Arabian-Nubian correlatives (Berhe 1990). Similarly to northeast Africa, the Brazilian ophiolites occur in the juvenile terranes identified in the Neoproterozoic Brasiliano Cycle orogenic belts, the Goiás magmatic arc in Central Brazil (Pimentel and Fuck 1992) and the Vila Nova belt (Figs. 1 and 2) in southern Brazil (Babinski et al. 1996). Smaller gravimetric anomalies (<30 mgal; Haralyi and Hasui 1982) indicate that the sutures were not active near the exposed ophiolites in the Brazilian Shield.

The 9-km long, harzburgite-amphibolite Cerro Mantiqueiras Ophiolite is a key geotectonic unit for the understanding of the southern Brazilian Shield evolution during the Neoproterozoic (Figs. 3 and 4). The goal of this investigation is to determine the geological evolution of the ophiolite based on field and microstructural relationships integrated with detailed, extensive electron-microprobe analyses of the minerals preserved from the sequential deformation of the basalts and peridotites.

\section{REGIONAL GEOLOGY}

Knowledge of the geological relationships in the southern Brazilian Shield (Fig. 1) has been improved by systematic investigations over the last fifty years, following the founding of the first undergraduate courses in Geology in Brazilian universities in 1957. Intense geological mapping by the Brazilian Geological Survey improved the understanding of many of the basic problems (Ramgrab et al. 1997, Porcher and Lopes 2000). Studies by staff and students from several Brazilian universities further expanded the knowledge of the geological relationships (e.g., Goñi 1962, Machado et al. 1987, Fernandes et al. 1992, Leite et al. 1998, Hartmann and Remus 2000, Hartmann et al. 1999a, b, 2000a, b, Remus et al. 2000).

We now know that the southern Brazilian Shield (Hartmann et al. 2000a) had an evolution comparable to the entire shield (Hartmann and Delgado 2001), because it contains some of the oldest granitic rocks $-3.41 \mathrm{Ga}$, La China Complex tonalites, which formed during the Uruguayan Cycle - 3.45-3.00 Ga. It also has rocks formed during the other orogenic cycles - Jequié Cycle, 2.952.66 Ga; Trans-Amazonian Cycle, 2.25-2.00 Ga; and Brasiliano Cycle, 1.0-0.55 Ga, all active during the episodic formation of the Brazilian Shield. Grenville-type orogenies - Sunsás Orogeny, 1.2-0.9 $\mathrm{Ga}$, occur in southwestern Amazon Craton (e.g., Sadowski and Bettencourt 1996) but have not been identified in the southern Brazilian Shield. The Brazilian Shield was cratonized at the end of the Brasiliano Cycle - at about $550 \mathrm{Ma}$, but younger orogenic deformation continued over $2000 \mathrm{~km}$ to the west to build the Andes.

The episodic orogenic deformation occurred at the active margins or within major Precambrian supercontinents (Hartmann 2002). The tectonic stability that followed the Trans-Amazonian Cycle is related to the existence of Supercontinent Atlantica - 2.00-1.00 Ga. Remnants of this supercontinent are known in the southern Brazilian Shield as the Rio de la Plata Craton. The intense deformation of the Neoproterozoic Brasiliano Cycle - 1.00-0.55 Ga formed the Supercontinent Gondwana, causing extensive crustal reworking of the Supercontinent Atlantica and juvenile accretion of TTG and ophiolites such as the Cerro Mantiqueiras Ophiolite.

This extended - 3.41-0.55 Ga, and polycyclic - four orogenic cycles, evolution of the continental crust left a complex imprint on the geological relationships in the southern Brazilian Shield. Ultramafic rocks are known from orogenic belts formed in all four orogenic cycles, but these are small $(<500$ $\mathrm{m})$ and intensely deformed; although some are associated with mafic rocks, it has not been possible to characterize them as part of ophiolites. On the contrary, they are more likely deformed komatiite lavas from these Archean and Paleoproterozoic belts (e.g., Hartmann et al. 2000b).

The search for ophiolites in this southwestern border of Gondwana has been concentrated in the Vila Nova terrane (Fig. 2), a Neoproterozoic juvenile association of TTG (tonalite-trondhjemitegranodiorite)-andesite-harzburgite. The Vila Nova 


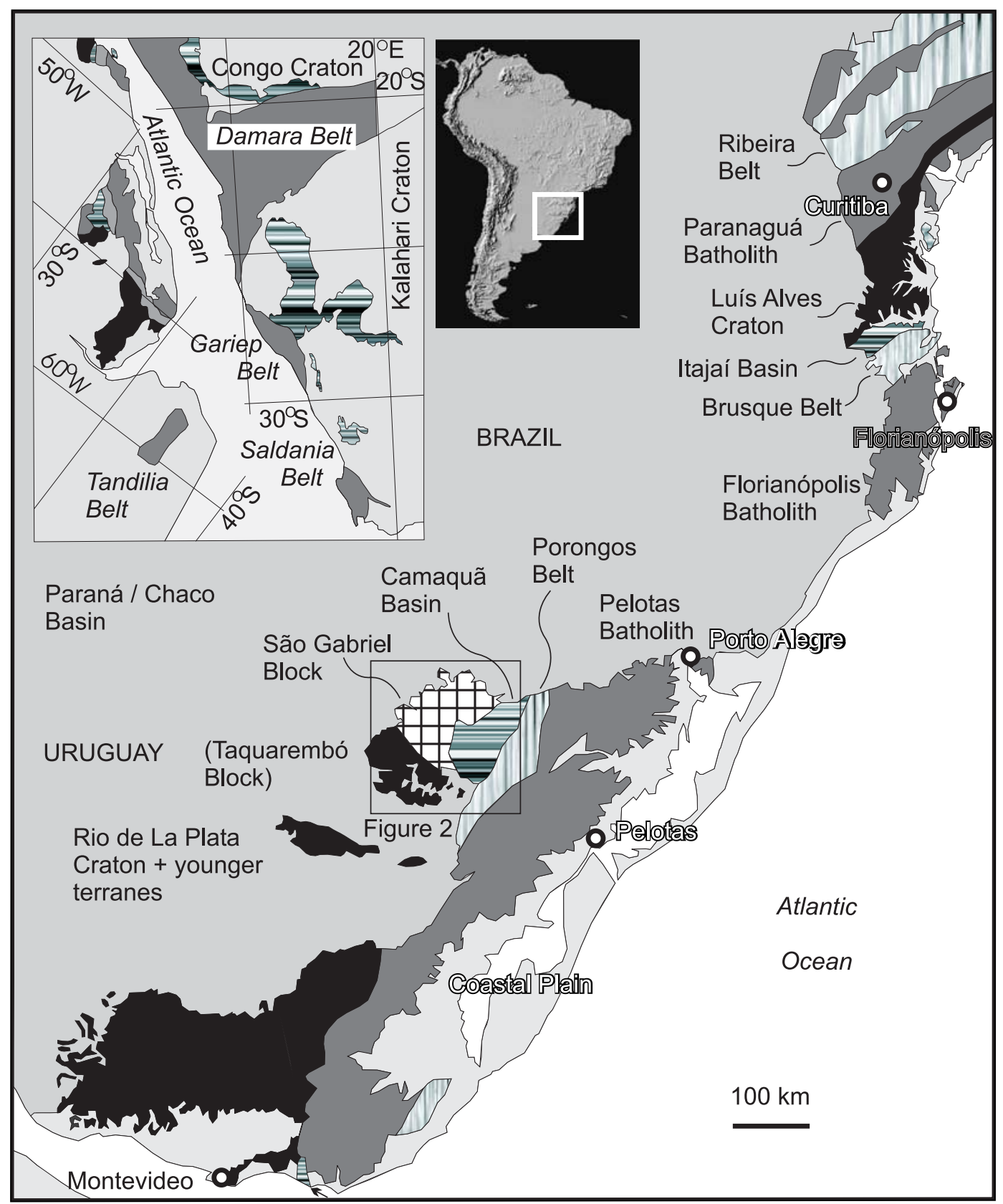

Fig. 1 - Geotectonic units of the southern Brazilian Shield (modified from Hartmann et al. 2000a) The Cerro Mantiqueiras Ophiolite is part of the São Gabriel Block. Location of Figure 2 indicated.

belt seems comparable to the Neoproterozoic juvenile Arabian-Nubian Shield, and it may contain ophiolite fragments as well. The juvenile Vila Nova belt is part of the São Gabriel Block, which was described by Jost and Hartmann (1984) as the geo- tectonic unit present in the western portion of the Brazilian Shield in the state of Rio Grande do Sul, because the geological, magmatic and metamorphic relationships of the block are not comparable to the eastern portion, known as the Dom Feliciano Belt 


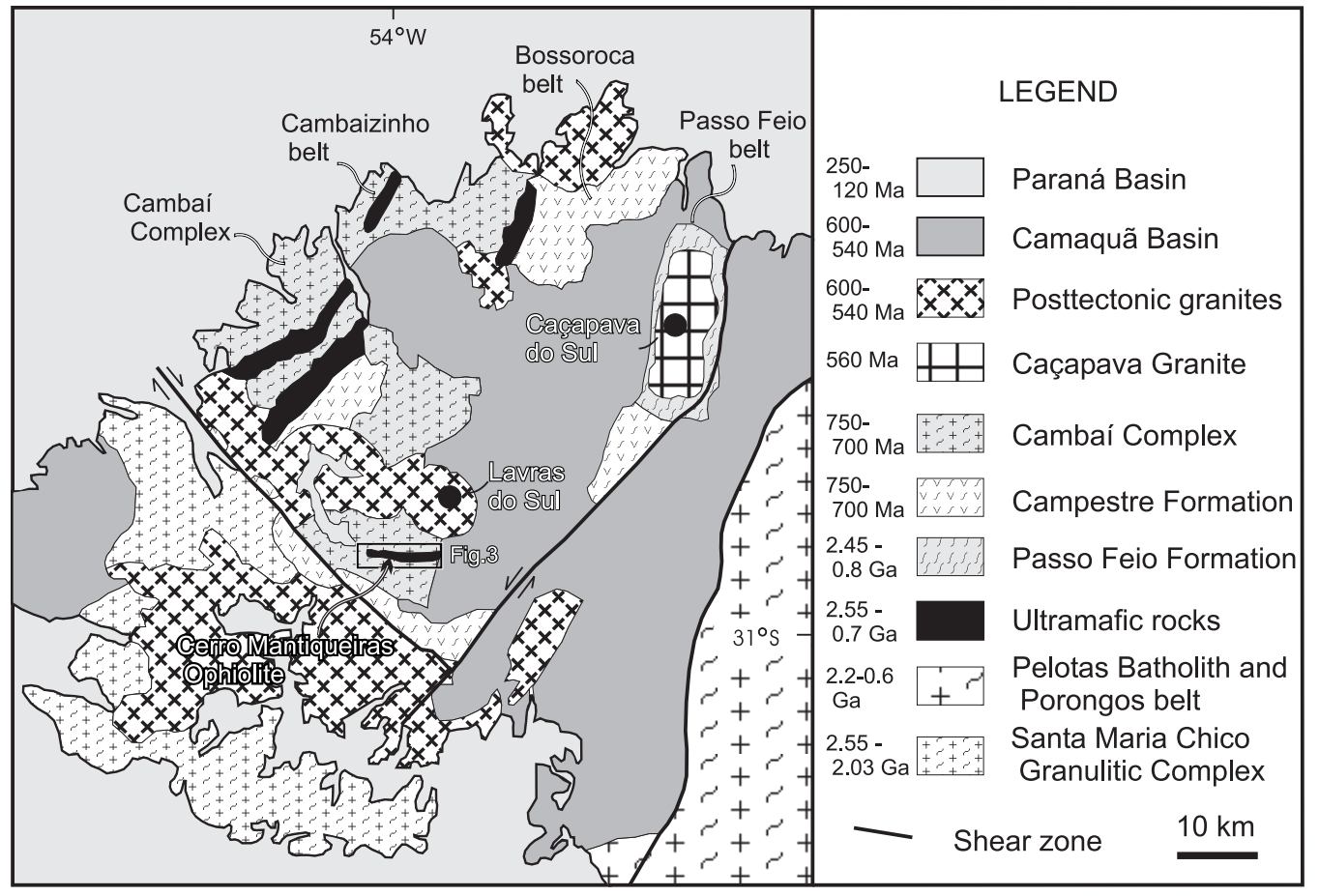

Fig. 2 - Geological map of the São Gabriel Block (modified from Hartmann et al. 1999a). Location of Cerro Mantiqueiras Ophiolite and Figure 3 indicated.

(Fragoso Cesar et al. 1986, Hartmann et al. 2000a). This concept has been consolidated by recent investigations in the southern Brazilian Shield, because only the São Gabriel Block contains (1) a major Archean/Paleoproterozoic granulitic unit - the Santa Maria Chico Complex (Hartmann et al. 1999a) and (2) a Neoproterozoic juvenile granitic/volcanic belt (Babinski et al. 1996). A Neoproterozoic shoshonitic to alkaline volcanic association (Lima and Nardi 1998) is also distinctive in the São Gabriel Block, although it extends over the basement to the east into the foreland Camaquã Basin. This basin covers the contact of the block with the Dom Feliciano Belt (Fragoso Cesar et al. 1986), a geotectonic unit formed by crustal reworking of the Paleoproterozoic Rio de la Plata Craton (e.g., Babinski et al. 1997, Frantz and Botelho 2000).

The São Gabriel Block has the largest volume of ultramafic rocks in the shield, including the investigated ophiolite. Metamorphosed ultramafic rocks are common in the block but form small massifs - 100-500 m-long. Magnesian schists, commonly containing talc-tremolite-chlorite, occur in the Passo Feio, Bossoroca and Cambaizinho belts and also in the Cambaí Complex (Fig. 2).

\section{GEOLOGY OF THE CERRO MANTIQUEIRAS OPHIOLITE}

The Cerro Mantiqueiras Ophiolite displays some outstanding geological features (Figs. 3 and 4), such as: (1) structural and metamorphic concordance between a $9 \mathrm{~km} \times 0.5 \mathrm{~km}$ body of harzburgite, rimmed by amphibolite, with the enclosing TTG association; (2) amphibolite of volcanic origin as seen in strongly deformed pillow lavas; (3) presence of metachert; (4) presence of a few 0.5 m-long massive chromitite pods; (5) monomineralic talc, chlorite and tremolite rocks along contacts of harzburgite with granitic rocks; (6) a few meter-sized, metassomatic blocks of albitite; (7) 


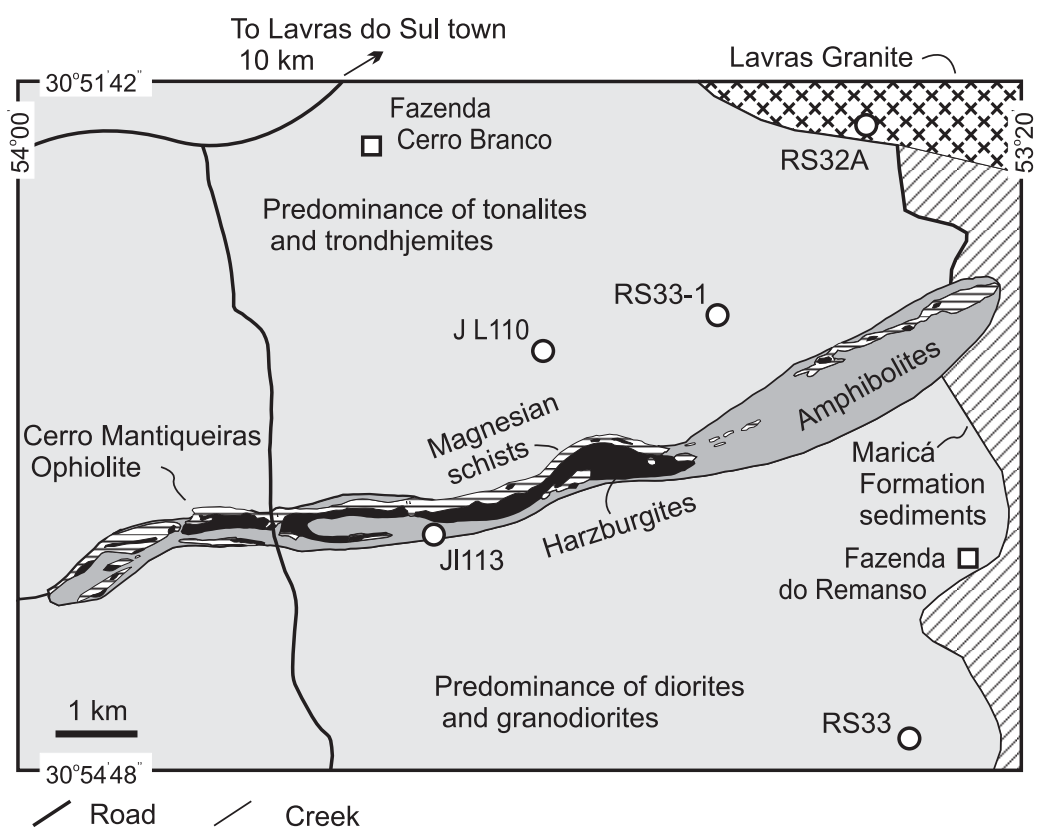

Fig. 3 - Regional geological map of Cerro Mantiqueiras Ophiolite (modified from R. Pinheiro Machado 1995, unpubl. and Leite 1997). Location of five samples dated by zircon U-Pb SHRIMP (Leite et al. 1998) indicated.

a one hundred-meter thick, talc-chlorite-tremoliteanthophyllite shear zone; (8) extensive serpentinization of the harzburgite, including some asbestosbearing, $1 \mathrm{~m}$-thick shear zones. Detailed gravimetric studies (J.A.D. Leite and F. Magro 1997, unpublished data) integrated with geological mapping at the 1:5000 scale show that the Cerro Mantiqueiras Ophiolite - harzburgite + serpentinite + magnesian schist + amphibolite, extends for $10 \mathrm{~km} \times 0.5 \mathrm{~km}$ to a depth of $11 \mathrm{~km}$ dipping $70^{\circ}$ to the south.

The harzburgites occur as elongated masses and pods with variable lengths $-5-350 \mathrm{~m}$, surrounded by the mylonitic magnesian schists. The pods are angulose blocks and boulders less than 20-30 m long. A thin grey to light red alteration film covers blocks and boulders; orthopyroxene is light grey and olivine is light red.

Harzburgites are well foliated to massive. Foliated rocks are medium to fine grained. The medium grained rocks have crystals from 0.5 to $2.0 \mathrm{~cm}$, and the rocks are banded and show thin discontinuous orthoyroxene-rich harzburgite bands up to $2 \mathrm{~cm}$ thick alternating with olivine-rich harzburgite bands. Fine grained rocks have mylonitic texture in which porphyroclastic relics of orthopyroxene and olivine lie in a fine grained mass of serpentine. Massive rocks are coarse grained, with grain size of olivine and orthopyroxene varying between 1 and $15 \mathrm{~cm}$. The texture is coarse granular xenoblastic with orthopyroxene and olivine showing interfingering contacts.

Serpentinites occur in two different settings. They form diffuse masses associated with the harzburgites and are grey to yellowish green, fine to very fine grained. Or else, the serpentinites occur in narrow 1-5 m-wide subvertical shear zones containing asbestos and cutting the harzburgite masses. In these zones, harzburgite blocks are immersed in a fine grained and well-foliated serpentinite matrix. These mylonitic serpentinites are black in fresh samples and greenish grey in altered samples. The remarkable geological relationships indicate a com- 


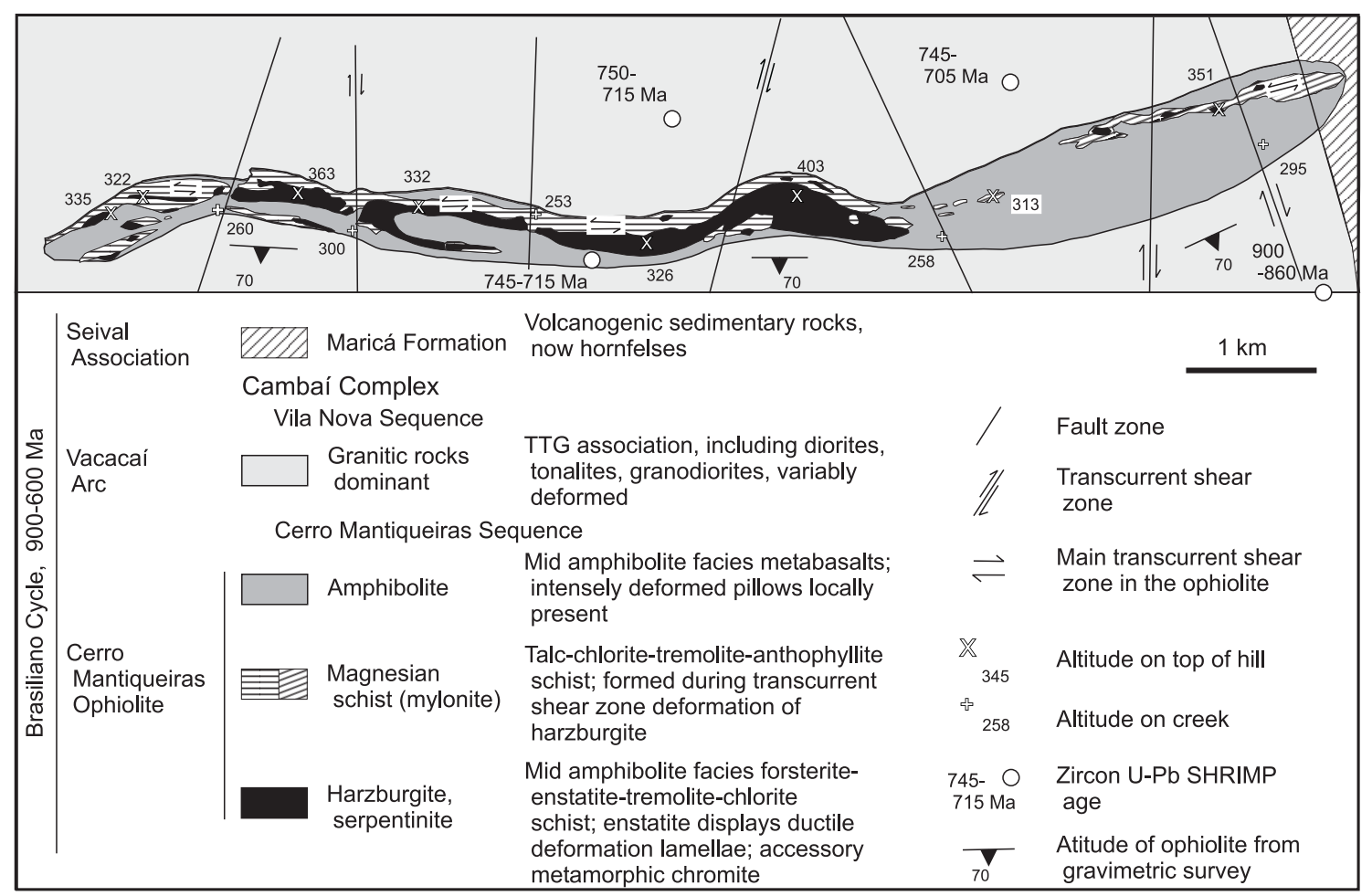

Fig. 4-Geological map of the Cerro Mantiqueiras Ophiolite (after Leite 1997). Transcurrent shear zones located from aerophotographs, field mapping and gravimetric anomalies.

plex succession of events in the formation of the ophiolite, and these can be observed with optical petrography.

\section{PETROGRAPHY}

The TTG rocks show evidence of recrystallization in the amphibolite facies, such as ductile deformation of feldspars, followed by greenschist facies, partial retrogressive alteration to chlorite and sericite. The amphibolites are plagioclase-hornblende rocks and show some retrogression to chlorite and actinolite. But the highly reactive, massive harzburgites display the most informative sequence of mineral assemblages for the understanding of metamorphic conditions attained during the evolution of the ophiolite.

The dominant mineral assemblage (Fig. 5) was formed during the highest grade of metamorphism registered in the harzburgites:

$$
\begin{gathered}
M_{1} \text { olivine }+ \text { orthopyroxene }+ \text { tremolite } \\
+ \text { chlorite }+ \text { chromite }
\end{gathered}
$$

The olivine crystals are tabular, 1-100 mm large in general but some crystals reach $150 \mathrm{~mm}$, strongly serpentinized and show no evidence of ductile deformation. Although length: width ratios of olivine crystals are near 1, some are elongated 2:1 and show negative optical elongation sign, a typical property of metamorphic olivine because its growth during metamorphism occurs along the $b$ crystallographic axis (e.g., Evans and Trommsdorf 1974). The orthopyroxene crystals are 1-80 mm across but may reach $150 \mathrm{~mm}$, and form radiating bundles. Small, 0.5 -mm crystals of olivine occur as inclusions in orthopyroxene and vice-versa, particularly near crystal rims. Orthopyroxene shows ductile deformation features such as ondulatory extinction, deformation lamellae and sub-grain formation. Tremolite and 


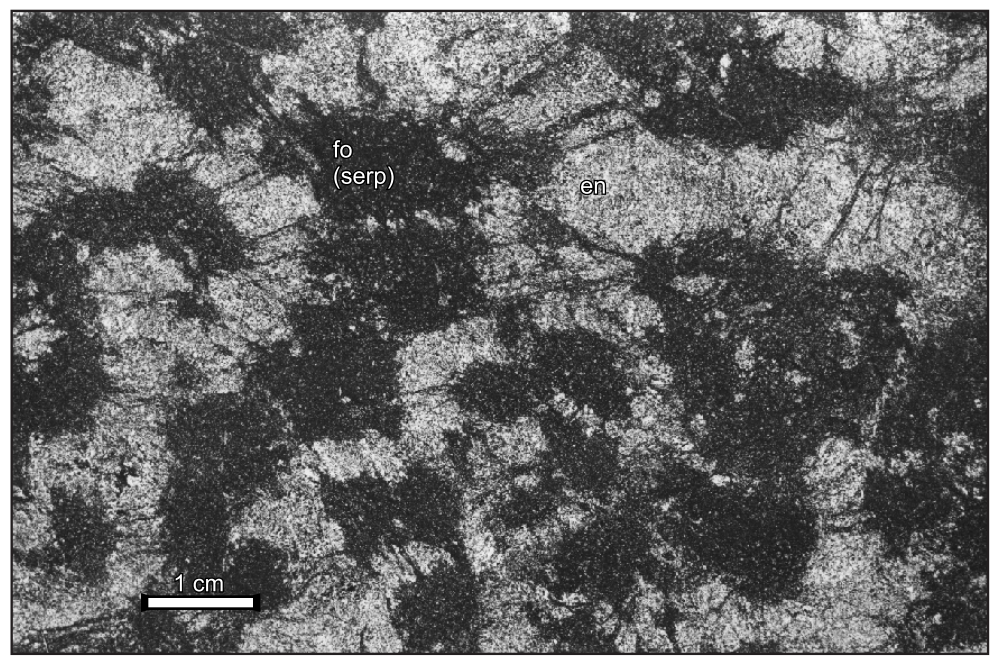

Fig. 5 - Photograph of hand sample of a harzburgite from the Cerro Mantiqueiras Ophiolite. Serpentinized forsterite is dark, enstatite is light grey. Serpentinization originated diffuse contacts between the two minerals. Radiating fractures around forsterite are due to expansion during serpentinization.

chlorite are not abundant, but occur as $1-10 \mathrm{~mm}$ crystals, in textural equilibrium with olivine and orthopyroxene. Chromite occurs as $1-5 \mathrm{~mm}$ large inclusions in olivine and orthopyroxene.

The following retrogressive mineral assemblage is dominant in the shear zone and occurs disseminated in the harzburgite:

$$
\begin{aligned}
M_{2} \quad \text { talc }+ \text { chlorite }+ \text { tremolite } \\
\quad( \pm \text { anthophyllite })+C r \text {-magnetite }
\end{aligned}
$$

These rocks are schistose and the grain size is about 0.5-1.0 mm.

Another assemblage occurs in small amounts in massive rocks:

$$
M_{2} \text { olivine }+ \text { talc }+C r \text {-magnetite }
$$

The generalized serpentinization of the harzburgite formed the assemblage:

$$
\begin{aligned}
& M_{3} \quad \text { serpentine }+ \text { Cr-magnetite } \\
& \quad+\text { chlorite }+ \text { talc }+ \text { tremolite }
\end{aligned}
$$

Spinel phases usually yield significant information regarding the origin and evolution of the host ultramafic rocks (e.g., Evans and Frost 1975, Irvine 1967, Dick and Bullen 1984, Sack and Ghiorso 1991, Suita and Strieder 1996, Candia and Gaspar 1996, Candia et al. 1999). In the Cerro Mantiqueiras Ophiolite, two types of spinels occur in the ultramafic rocks, Cr-magnetite and chromite, and both occur either disseminated in the ultramafic rocks or massive in 20-30 cm-long pods. Spinel crystals are anhedral to subhedral, about $0.1-4.0 \mathrm{~mm}$ in size and commonly have thin $0.01 \mathrm{~mm}$ rims of Cr-magnetite. Six massive $\mathrm{Cr}$-magnetite and chromite pods have been identified in the ophiolite. The disseminated spinels are commonly included in olivine and orthopyroxene but also occur in intercrystalline positions and are very fine grained $-0.01-0.25 \mathrm{~mm}$. Cr-magnetite also occurs as fine to very fine grained crystals, and forms clouds in the silicates, widely distributed in the harzburgites. In short, two types of spinel occur in terms of grain size; the very fine to fine grained crystals are Cr-magnetite, whereas the fine to coarse grained crystals may be either $\mathrm{Cr}$-magnetite or Fe-chromite. The largest $\mathrm{Cr}$-spinel crystals are slightly richer in $\mathrm{Cr}_{2} \mathrm{O}_{3}$ and are partly corroded by chlorite. 
TABLE I

Selected chemical analyses (wt\% oxides) of olivines from Cerro Mantiqueiras Ophiolite harzburgites by electron microprobe.

$\mathrm{Al}_{2} \mathrm{O}_{3}$ not detected. Total number of olivine analyses $\mathrm{n}=157$.

\begin{tabular}{l|c|c|c|c|c}
\hline Analysis & 1 & 2 & 3 & 4 & 5 \\
\hline $\mathrm{SiO}_{2}$ & 39.22 & 40.84 & 40.59 & 40.16 & 41.16 \\
$\mathrm{TiO}_{2}$ & 0.00 & 0.00 & 0.00 & 0.02 & 0.00 \\
$\mathrm{Cr}_{2} \mathrm{O}_{3}$ & 0.00 & 0.00 & 0.05 & 0.00 & 0.00 \\
$\mathrm{FeO}$ & 12.45 & 9.84 & 9.28 & 8.62 & 7.53 \\
$\mathrm{NiO}$ & 0.29 & 0.42 & 0.33 & 0.31 & 0.23 \\
$\mathrm{MnO}$ & 0.12 & 0.16 & 0.16 & 0.09 & 0.12 \\
$\mathrm{MgO}$ & 47.40 & 49.41 & 49.80 & 49.88 & 51.62 \\
$\mathrm{CaO}$ & 0.01 & 0.00 & 0.00 & 0.01 & 0.00 \\
$\mathrm{Total}$ & 99.51 & 100.70 & 100.26 & 99.13 & 100.69 \\
\multicolumn{5}{|c|}{$\mathrm{Structural}$ formulae on the basis of 40} \\
$\mathrm{Si}$ & 0.98 & 0.99 & 0.99 & 0.98 & 0.99 \\
$\mathrm{Ti}$ & 0.00 & 0.00 & 0.00 & 0.00 & 0.00 \\
$\mathrm{Cr}$ & 0.00 & 0.00 & 0.00 & 0.00 & 0.00 \\
$\mathrm{Fe}$ & 0.26 & 0.20 & 0.18 & 0.17 & 0.15 \\
$\mathrm{Ni}$ & 0.00 & 0.00 & 0.00 & 0.00 & 0.00 \\
$\mathrm{Mn}$ & 0.00 & 0.00 & 0.00 & 0.00 & 0.00 \\
$\mathrm{Mg}$ & 1.76 & 1.79 & 1.81 & 1.83 & 1.85 \\
$\mathrm{Ca}$ & 0.00 & 0.00 & 0.00 & 0.00 & 0.00 \\
$\mathrm{Fo}$ & 87.06 & 89.90 & 90.38 & 91.08 & 92.32 \\
\hline
\end{tabular}

\section{ELECTRON MICROPROBE RESULTS}

The extensive chemical investigation - 495 analyses, of the harzburgite minerals - olivine, orthopyroxene, tremolite, chlorite and spinel, by electron microprobe led to the detailed description and to an advanced understanding of the metamorphic processes involved. Full tables containing the results of electron microprobe analyses of minerals can be obtained from the authors; only representative analyses are published here. The 157 analyses of olivine (Table I) show that the composition varies between $\mathrm{Fo}_{87.1}$ and $\mathrm{Fo}_{92.3}$ (Fig. 6). The crystals are unzoned and show little chemical variation between grains from the same sample or even when crystals from different samples are compared.

The trace element contents $(\mathrm{NiO}$ and $\mathrm{MnO})$ of $\mathrm{M}_{1}$ forsterite (Fig. 6) indicate compositions sim- ilar to mantle or high grade, crustal metamorphic olivine. The field for mantle compositions is indicated in Fig. 6, and the field for high grade metamorphic olivine can be estimated by extending the compositions from the low metamorphic grade field through the tremolite-talc field into higher $\mathrm{NiO}$ (Fig. 6a) or lower $\mathrm{MnO}$ and higher Fo contents of olivine (Fig. 6b). Some analyses are similar to olivines from low-amphibolite facies (tremolite-talc field), probably as a result of retrogressive alteration during $\mathrm{M}_{2}$ metamorphism.

Orthopyroxene ( $\mathrm{n}=143$ analyses) has a compositional variation (Table II) between $\mathrm{En}_{89.0}-\mathrm{En}_{93.8}$ and little variation when different samples are compared. Strained orthpyroxene has similar composition as the other orthopyroxene crystals. No significant zoning of individual crystals is observed.

The 123 spinel analyses (Table III) from the 

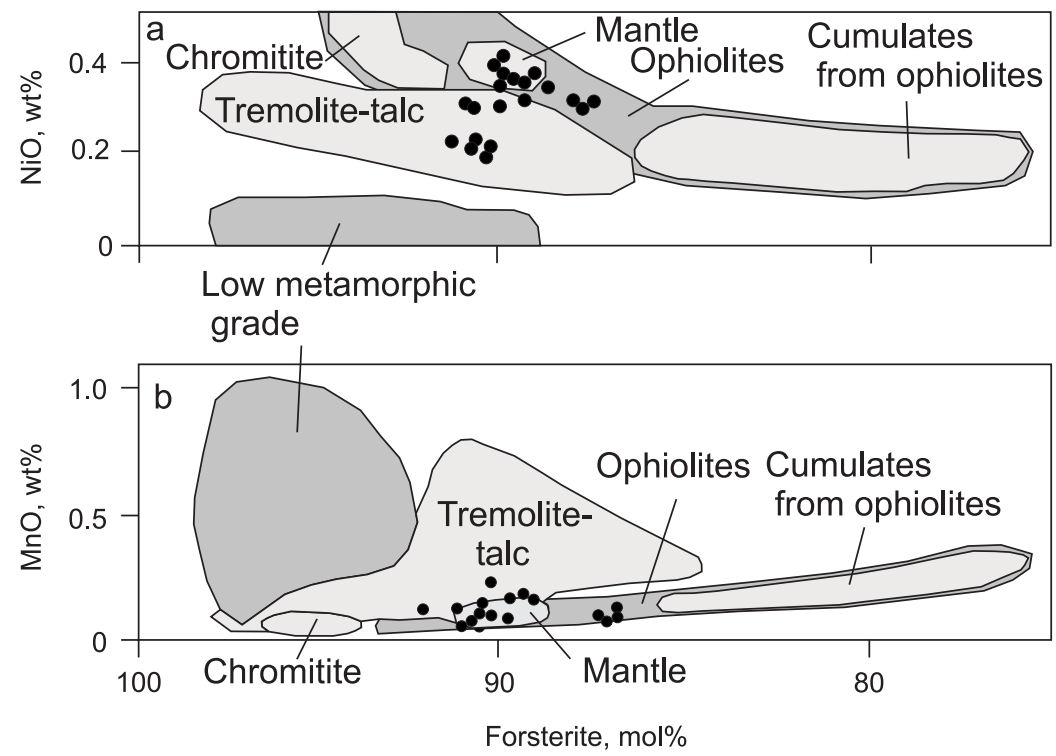

Fig. 6 - Selected chemical analyses of forsterite by electron microprobe from the Cerro Mantiqueiras Ophiolite; compositional fields from Vance and Dungan (1977) shown for comparison. Recrystallization of forsterite in amphibolite facies is indicated, although some compositions plot in the mantle or ophiolite compositional fields.

Cerro Mantiqueiras harzburgites and pods show that the compositions are rather variable. Cr-magnetite is the dominant disseminated spinel present, as seen from the chemical analyses $(\mathrm{wt} \%)-\mathrm{Al}_{2} \mathrm{O}_{3}, 0.01$ 1.3; $\mathrm{TiO}_{2}, 0.00-0.20 ; \mathrm{Cr}_{2} \mathrm{O}_{3}, 0.06-24.73 ; \mathrm{Fe}_{2} \mathrm{O}_{3}$, 41-67; $\mathrm{MgO}, 0.1-4.5$; FeO, 22-30. This is also indicated by $\mathrm{Fe}^{2+} / \mathrm{Mg}=6.9-300.0, \mathrm{Cr} / \mathrm{Al}=0.1-17.0$, $\# \mathrm{Mg}=0.02-0.16, \# \mathrm{Cr}=0.85-0.94, \# \mathrm{Fe}=0.83-0.99$. The chemical compositions of the analyzed disseminated spinels are different from massive podiform and stratiform chromites from other regions (Fig. 7), and more comparable to compositions of upper greenschist and amphibolite facies spinels.

One sample of harzburgite was investigated in more detail, because it contains spinel inclusions in plastically deformed orthopyroxene. If the orthopyroxene were a relict mantle phase, then the chemical composition of the spinel would probably approximate to mantle spinels. The chemical analyses of these spinel inclusions show that their compositions are identical within error with the other $\mathrm{Cr}$ magnetites from the harzburgites (Fig. 7). A mantle origin for the orthopyroxene and included spinel has not been demonstrated, therefore.

The investigation of five spinel crystals from two massive pods included chemical analyses along $1000 \mu \mathrm{m}$-long profiles, individual analyses spaced $50 \mu \mathrm{m}$. The cores of the crystals are Fe-chromite and $\mathrm{Cr}$-magnetite and the rims are Cr-magnetite. The massive spinels have the following chemical compositions ( $\mathrm{wt} \%$ ) in the profiles analyzed: $\mathrm{Al}_{2} \mathrm{O}_{3}$, 4.16-5.80; $\mathrm{TiO}_{2}, 0.01-0.07 ; \mathrm{Cr}_{2} \mathrm{O}_{3}, 27-50 ; \mathrm{Fe}_{2} \mathrm{O}_{3}$, 14-35; $\mathrm{MgO}, 4.5-6.8 ; \mathrm{FeO}, 21-23$. Some of the ratios between cations are: $\# \mathrm{Mg}=0.16-0.24 ; \# \mathrm{Cr}=$ 0.82-0.91; $\# \mathrm{Fe}=0.75-0.77 ; \mathrm{Cr} / \mathrm{Al}=6.6-11.2$. Some of the chemical analyses made on many spinel crystals show some minor differences in the profiles. In general, the highest $\mathrm{Al}_{2} \mathrm{O}_{3}$ and $\mathrm{Cr}_{2} \mathrm{O}_{3}$ contents are in the center of the spinel crystals. Chemical discrimination diagrams indicate that these massive Fe-chromites and Cr-magnetites are different from massive stratiform or ophiolite podiform spinels and more comparable to low to medium grade metamorphic spinels (Fig. 7). These discrimination dia- 
TABLE II

Selected chemical analyses (wt\% oxides) of orthopyroxenes from Cerro Mantiqueiras Ophiolite harzburgites by electron microprobe. $\mathrm{Na}_{2} \mathrm{O}$ and $\mathrm{NiO}$ undetected. Total number of orthopyroxene analyses $n=143$.

\begin{tabular}{|c|c|c|c|c|c|}
\hline Analysis & 6 & 7 & 8 & 9 & 10 \\
\hline $\mathrm{SiO}_{2}$ & 57.12 & 56.46 & 57.80 & 57.08 & 58.32 \\
\hline $\mathrm{TiO}_{2}$ & 0.01 & 0.00 & 0.03 & 0.01 & 0.02 \\
\hline $\mathrm{Al}_{2} \mathrm{O}_{3}$ & 0.26 & 0.21 & 0.23 & 0.31 & 0.22 \\
\hline $\mathrm{Cr}_{2} \mathrm{O}_{3}$ & 0.05 & 0.05 & 0.04 & 0.17 & 0.23 \\
\hline $\mathrm{Fe}_{2} \mathrm{O}_{3}$ & 1.19 & 2.60 & 0.44 & 1.97 & 0.77 \\
\hline $\mathrm{FeO}$ & 7.23 & 6.36 & 6.04 & 4.89 & 4.24 \\
\hline $\mathrm{MnO}$ & 0.16 & 0.14 & 0.11 & 0.10 & 0.05 \\
\hline $\mathrm{MgO}$ & 34.10 & 34.16 & 35.33 & 35.45 & 36.71 \\
\hline $\mathrm{CaO}$ & 0.11 & 0.08 & 0.01 & 0.06 & 0.01 \\
\hline Total & 100.27 & 100.10 & 100.08 & 100.08 & 100.60 \\
\hline \multicolumn{6}{|c|}{ Structural formulae on the basis of 60} \\
\hline $\mathrm{Si}$ & 1.97 & 1.96 & 1.98 & 1.96 & 1.98 \\
\hline $\mathrm{Ti}$ & 0.00 & 0.00 & 0.00 & 0.00 & 0.00 \\
\hline $\mathrm{Al}$ & 0.01 & 0.00 & 0.00 & 0.01 & 0.00 \\
\hline $\mathrm{Cr}$ & 0.00 & 0.00 & 0.00 & 0.00 & 0.00 \\
\hline $\mathrm{Fe}^{3+}$ & 0.03 & 0.06 & 0.01 & 0.05 & 0.01 \\
\hline $\mathrm{Fe}^{2+}$ & 0.20 & 0.18 & 0.17 & 0.14 & 0.12 \\
\hline $\mathrm{Mn}$ & 0.00 & 0.00 & 0.00 & 0.00 & 0.00 \\
\hline $\mathrm{Mg}$ & 1.75 & 1.76 & 1.81 & 1.81 & 1.85 \\
\hline $\mathrm{Ca}$ & 0.00 & 0.00 & 0.00 & 0.00 & 0.00 \\
\hline En & 88.96 & 90.19 & 91.08 & 92.55 & 93.81 \\
\hline Fs & 10.82 & 9.65 & 8.90 & 7.33 & 6.17 \\
\hline Wo & 0.22 & 0.10 & 0.09 & 0.12 & 0.02 \\
\hline
\end{tabular}

grams are presently used integrated with the geological, microstructural and geochemical evidence, because otherwise they may lead to incorrect conclusions (Kimball 1990, Candia and Gaspar 1996, Power et al. 2000).

The amphiboles in the harzburgites were extensively investigated on the electron microprobe with the EDS and 43 WDS chemical analyses (Table IV). Only tremolite was identified, both in well formed, larger crystals from the $\mathrm{M}_{1}$ assemblage and in smaller prisms from the $\mathrm{M}_{2}$ and possibly $\mathrm{M}_{3}$ assemblages. Chlorite analyses $(n=29$, Table V) show highly magnesian compositions, close to clinochlore. Chemical analyses $(n=34)$ of two albite crystals from a metassomatic albitite show average composition of $\mathrm{Ab}_{95} \mathrm{An}_{3} \mathrm{Or}_{2}$.

\section{METAMORPHIC EVOLUTION}

The sequence of events from $\mathrm{M}_{1} \rightarrow \mathrm{M}_{2} \rightarrow \mathrm{M}_{3} \rightarrow$ $\mathrm{M}_{4}$ is illustrated in Figure 8. The $\mathrm{M}_{1}$ mineralogical assemblage of the harzburgite in the ophiolite is characteristic of metamorphic harzburgites recrystallized in the mid amphibolite facies (Evans and Trommsdorf 1974, Evans 1977, Bucher and Frey 
TABLE III

Selected chemical analyses (wt\% oxides) of $\mathrm{Cr}$-spinels from Cerro Mantiqueiras Ophiolite harzburgites by electron microprobe. Total number of spinel analyses $n=123$.

\begin{tabular}{l|c|c|c|c|c}
\hline Analysis & 11 & 12 & 13 & 14 & 15 \\
\hline $\mathrm{TiO}_{2}$ & 1.30 & 0.24 & 0.24 & 0.23 & 0.31 \\
$\mathrm{Al}_{2} \mathrm{O}_{3}$ & 0.54 & 2.50 & 3.58 & 1.67 & 6.49 \\
$\mathrm{Cr}_{2} \mathrm{O}_{3}$ & 19.58 & 34.96 & 35.91 & 36.27 & 46.84 \\
$\mathrm{Fe}_{2} \mathrm{O}_{3}$ & 45.55 & 30.92 & 28.65 & 30.85 & 14.43 \\
$\mathrm{MgO}$ & 1.28 & 2.96 & 3.39 & 2.71 & 5.25 \\
$\mathrm{FeO}$ & 30.19 & 27.35 & 26.78 & 27.77 & 24.40 \\
$\mathrm{NiO}$ & 0.23 & 0.36 & 0.32 & 0.32 & 0.22 \\
$\mathrm{ZnO}$ & 0.12 & 0.21 & 0.21 & 0.21 & 0.49 \\
$\mathrm{Total}$ & 98.83 & 99.53 & 99.12 & 100.06 & 98.45 \\
\multicolumn{5}{|c|}{$\mathrm{Structural}$ formulae on the basis of 32O } \\
$\mathrm{Ti}$ & 0.29 & 0.05 & 0.05 & 0.05 & 0.06 \\
$\mathrm{Al}$ & 0.19 & 0.86 & 1.23 & 0.57 & 2.17 \\
$\mathrm{Cr}$ & 4.71 & 8.12 & 8.29 & 8.43 & 10.52 \\
$\mathrm{Fe}$ & 10.44 & 6.83 & 6.29 & 6.82 & 3.08 \\
$\mathrm{Mg}$ & 0.58 & 1.29 & 1.47 & 1.19 & 2.22 \\
$\mathrm{Fe}$ & 7.69 & 6.83 & 6.54 & 6.82 & 5.80 \\
$\mathrm{Ni}$ & 0.05 & 0.08 & 0.07 & 0.07 & 0.05 \\
$\mathrm{Zn}$ & 0.02 & 0.04 & 0.04 & 0.04 & 0.10 \\
$\mathrm{Cr} / \mathrm{Cr}+\mathrm{Al}$ & 0.96 & 0.90 & 0.87 & 0.93 & 0.82 \\
$\mathrm{X}$ & 0.07 & 0.16 & 0.18 & 0.14 & 0.22 \\
\hline $\mathrm{Mg}$ & \multicolumn{5}{|c}{}
\end{tabular}

2002). Olivine is stable in the entire amphibolite facies in ultramafic rocks, but orthopyroxene is only stable in the mid amphibolite facies and higher grades. Tremolite is stable in the whole amphibolite facies, because clinopyroxene only crystallizes in the granulite facies in harzburgites and was only observed in the Cerro Mantiqueiras Ophiolite amphibolites, not in the harzburgites. Chlorite is stable in low to mid amphibolite facies, and becomes unstable in the upper amphibolite facies where it is replaced by picotite (Cr-hercynite). Picotite was not observed in the investigated harzburgites. The chemical composition of chromite is typical of amphibolite facies spinels.

In summary, the $\mathrm{M}_{1}$ mineralogical assemblage was formed during regional metamorphism in the mid amphibolite facies, because olivine, orthopyroxene, tremolite and chlorite occur in a stable assemblage and no clinopyroxene or picotite were observed in the harzburgites. The spinel compositions are also compatible with equilibration in mid amphibolite facies metamorphic conditions in the crust.

From the petrographic observations and electron microprobe chemical analyses, no remnant mantle mineralogy was encountered. Olivine and chromite are fractured but do not display ductile deformation indicative of mantle deformation. The ondulatory extinction shown by many crystals of orthopyroxene is attributed to deformation occurring late during the amphibolite facies metamorphic event, as is common in cratonic ultramafic complexes. The detailed chemical investigation of 
TABLE IV

Selected chemical analyses (wt $\%$ oxides) of tremolites from Cerro Mantiqueiras Ophiolite harzburgites by electron microprobe. Total number of tremolite analyses $n=43$.

\begin{tabular}{|c|c|c|c|}
\hline Analysis & 16 & 17 & 18 \\
\hline $\mathrm{SiO}_{2}$ & 55.12 & 57.40 & 54.45 \\
\hline $\mathrm{TiO}_{2}$ & 0.02 & 0.04 & 0.06 \\
\hline $\mathrm{Al}_{2} \mathrm{O}_{3}$ & 0.93 & 0.76 & 0.75 \\
\hline $\mathrm{FeO}$ & 2.93 & 2.28 & 2.64 \\
\hline $\mathrm{MnO}$ & 0.08 & 0.09 & 0.13 \\
\hline $\mathrm{MgO}$ & 24.57 & 24.34 & 27.27 \\
\hline $\mathrm{CaO}$ & 10.65 & 12.07 & 9.87 \\
\hline $\mathrm{Cr}_{2} \mathrm{O}_{3}$ & 0.12 & 0.12 & 0.09 \\
\hline $\mathrm{Na}_{2} \mathrm{O}$ & 0.17 & 0.16 & 0.18 \\
\hline $\mathrm{K}_{2} \mathrm{O}$ & 0.01 & 0.01 & 0.01 \\
\hline Total & 94.60 & 97.27 & 95.45 \\
\hline
\end{tabular}

Structural formulae on the basis of 230

\begin{tabular}{l|l|l|l}
$\mathrm{Si}$ & 7.79 & 7.87 & 7.63 \\
$\mathrm{Ti}$ & 0.00 & 0.00 & 0.01 \\
$\mathrm{Al}$ & 0.15 & 0.12 & 0.12 \\
$\mathrm{Fe}$ & 0.35 & 0.26 & 0.31 \\
$\mathrm{Mn}$ & 0.01 & 0.01 & 0.01 \\
$\mathrm{Mg}$ & 5.17 & 4.98 & 5.70 \\
$\mathrm{Ca}$ & 1.61 & 1.77 & 1.48 \\
$\mathrm{Cr}$ & 0.01 & 0.01 & 0.01 \\
$\mathrm{Na}$ & 0.04 & 0.04 & 0.05 \\
$\mathrm{~K}$ & 0.00 & 0.00 & 0.00 \\
\hline
\end{tabular}

chromite crystals from massive chromitites and those included in orthopyroxene that shows ondulatory extinction also indicates compositions comparable to amphibolite facies crystals.

The harzburgite was therefore entirely recrystallized during and after its emplacement in the crust, because no remnant mantle minerals were identified. Its present position is the result of crustal deformation in metamorphic conditions about $550-600^{\circ} \mathrm{C}$ or slightly higher in mid amphibolite facies (Fig. 9). The Jackson (1969) geothermometer tends to yield temperatures which are unrealistically high (Sack and Ghiorso, 1991), but Fig. 9 indicates that man- tle temperatures $\left(>1000^{\circ} \mathrm{C}\right)$ are not preserved in the analyzed mineral pairs (Appendix 2).

The metamorphic conditions prevailing during $\mathrm{M}_{2}$ were retrogressive in the low amphibolite facies, because anthophyllite is stable in association with talc, chlorite and tremolite and olivine occurs in equilibrium with talc. Orthopyroxene is not stable in these conditions and was not found in the assemblage. Temperatures during this metamorphic event $\mathrm{M}_{2}$ were about $500-550^{\circ} \mathrm{C}$ or slightly higher (Fig. 9). $M_{3}$ occurred in the greenschist facies because of the abundance of serpentine.

The formation of the monomineralic rocks 


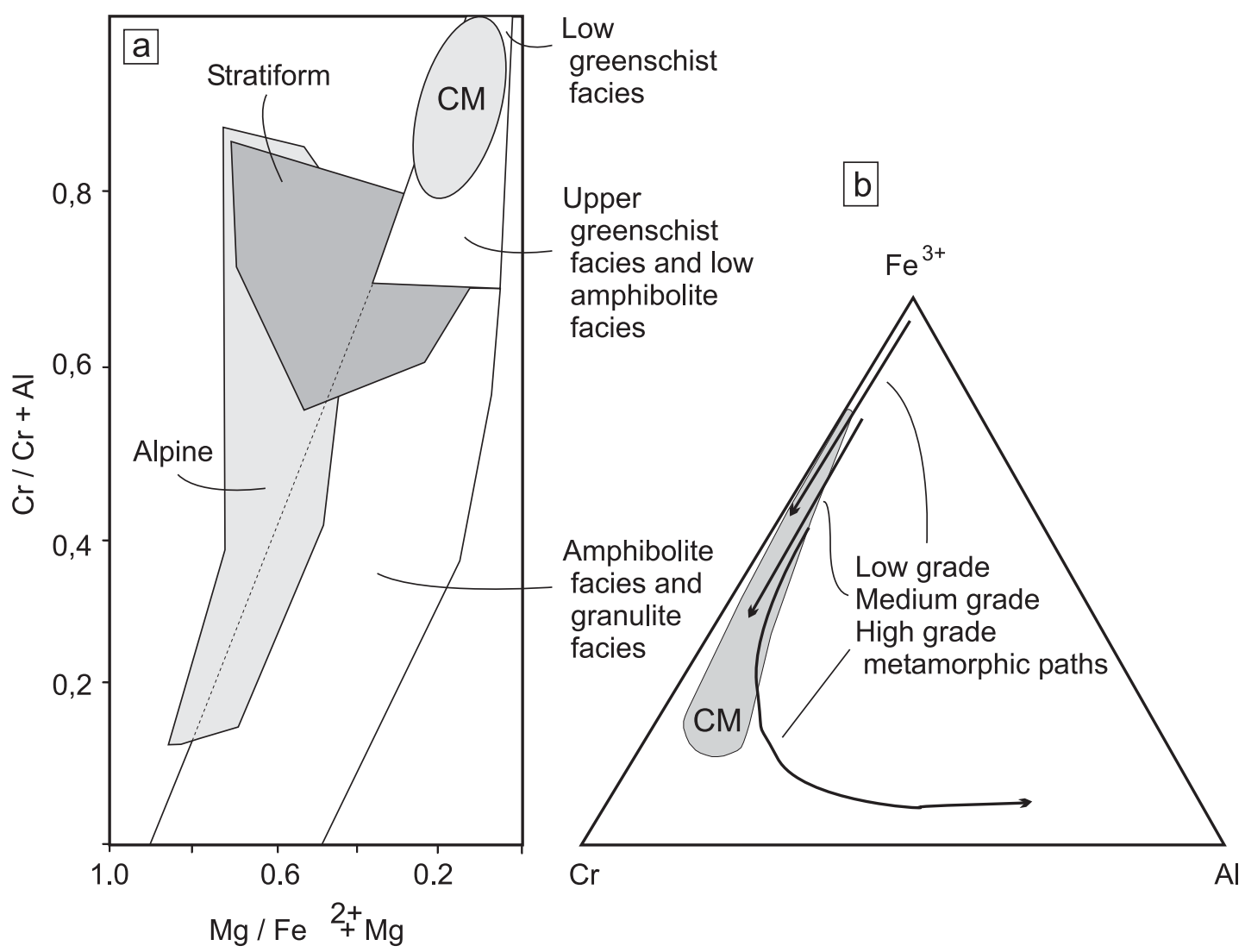

Fig. 7 - Selected chemical analyses by electron microprobe of disseminated and massive chromites from the Cerro Mantiqueiras Ophiolite (indicated by CM) compared (a) with other tectonic associations (Irvine, 1967) and (b) metamorphic grades (Evans and Frost 1975).

composed of talc, tremolite, chlorite or albite and present at the contact with the granites is interpreted as occurring before $\mathrm{M}_{1}$, because there is no field or petrographic evidence linking this intense metassomatic event to the $\mathrm{M}_{3}$ serpentinization event. The formation of thick blackwall reaction zones and albitites requires extensive serpentinization of the ultramafic rock, because many trace elements (e.g. $\mathrm{Na}_{2} \mathrm{O}, \mathrm{K}_{2} \mathrm{O}, \mathrm{Al}_{2} \mathrm{O}_{3}, \mathrm{CaO}$ ) are unable to enter the serpentine structure and thus migrate to the wall rocks and dykes. Thus, the $\mathrm{M}_{1}$ mineralogical assemblage of the harzburgite is interpreted as the result of mid amphibolite facies recrystallization of a serpentinite. The albitite and zoned blackwall were recrystallized along with the serpentinite but the mineralogy did not change much because a similar assemblage was stable in the new amphibolite facies conditions.

The metamorphic evolution of the Cerro Mantiqueiras Ophiolite included, in our interpretation, an initial, strong greenschist facies event of serpentinization and associated metasomatic formation of albitite and chloritic blackwall. The harzburgite is interpreted therefore as a meta-serpentinite. But the strong overprint of amphibolite facies metamorphism precludes the petrographic investigation of the metasomatic processes.

This extended metamorphic evolution was responsible for the obliteration of textures and mineralogy which had possibly originated in the mantle before the Neoproterozoic emplacement of the ophiolite into the juvenile portion of the southern Brazilian crust. The initial serpentinization was very 


\section{TABLE V}

Selected chemical analyses (wt\% oxides) of chlorites from Cerro Mantiqueiras Ophiolite harzburgites by electron microprobe. $\mathrm{TiO}_{2}, \mathrm{NiO}, \mathrm{MnO}, \mathrm{CaO}, \mathrm{Na}_{2} \mathrm{O}$, $\mathrm{K}_{2} \mathrm{O}$ and $\mathrm{Cl}$ not detected. Total number of chlorite analyses $n=29$.

\begin{tabular}{l|c|c|c|c|c}
\hline Analysis & 21 & 22 & 23 & 24 & 25 \\
\hline $\mathrm{SiO}_{2}$ & 31.30 & 31.07 & 33.98 & 32.27 & 31.11 \\
$\mathrm{Al}_{2} \mathrm{O}_{3}$ & 15.92 & 16.27 & 12.51 & 16.07 & 15.89 \\
$\mathrm{Cr}_{2} \mathrm{O}_{3}$ & 1.15 & 1.74 & 1.87 & 1.77 & 2.23 \\
$\mathrm{FeO}$ & 5.32 & 3.05 & 3.50 & 3.74 & 3.29 \\
$\mathrm{MgO}$ & 31.70 & 32.69 & 34.17 & 33.22 & 32.21 \\
$\mathrm{Total}$ & 85.40 & 84.88 & 86.03 & 87.07 & 84.73 \\
\multicolumn{5}{|c|}{ Structural formulae on the basis of 28O } \\
$\mathrm{Si}$ & 6.09 & 6.03 & 6.51 & 6.11 & 6.06 \\
$\mathrm{Al}$ & 3.65 & 3.72 & 2.82 & 3.59 & 3.64 \\
$\mathrm{Cr}$ & 0.17 & 0.26 & 0.28 & 0.26 & 0.34 \\
$\mathrm{Fe}$ & 0.86 & 0.49 & 0.56 & 0.59 & 0.53 \\
$\mathrm{Mg}$ & 9.19 & 9.46 & 9.75 & 9.38 & 9.35 \\
\hline
\end{tabular}

intense, because rather thick blackwall rocks were formed. This serpentinization presumably recrystallized entirely all the silicates and spinels into low temperature minerals such as serpentine, talc, tremolite, brucite, chlorite and Cr-magnetite. Any surviving mantle mineralogy was later recrystallized during progressive metamorphism to greenschist and amphibolite facies assemblages, leaving no trace of pre- $\mathrm{M}_{1}$ textures, structures or minerals.

\section{CONCLUSIONS}

The investigation of the Neoproterozoic Cerro Mantiqueiras Ophiolite from southwestern Gondwana was based on field, petrographic and electron microprobe techniques and resulted in the understanding of the following evolutionary steps:

1. Presumed emplacement of the mantle peridotite into the crust;

2. Thorough serpentinization of the peridotite, with the destruction of most or all mantlegenerated microstructures and mineralogy. Metasomatic monomineralic rocks formed near contacts with granitic rocks, containing albite, chlorite, tremolite or talc.

3. Progressive metamorphism leading to the recrystallization of any remaining mantle characteristics of the ultramafic rocks and the formation of the M1 mineralogical assemblage in mid amphibolite facies - olivine + enstatite + tremolite + chlorite + chromite. This is the oldest crustal event recorded in the harzburgite.

4. $\mathrm{M}_{2}$ shear zone metamorphism of the harzburgite in shear zones, forming the low amphibolite facies assemblage talc + chlorite + tremolite (+anthophyllite $)+$ Cr-magnetite .

5. $\mathrm{M}_{3}$ extensive serpentinization of the ophiolite.

6. $\mathrm{M}_{4}$ generation of narrow shear zones containing asbestos.

\section{APPENDIX 1 MATERIALS AND METHODS}

Geological mapping of the Cerro Mantiqueiras Ophiolite was undertaken for this investigation in 


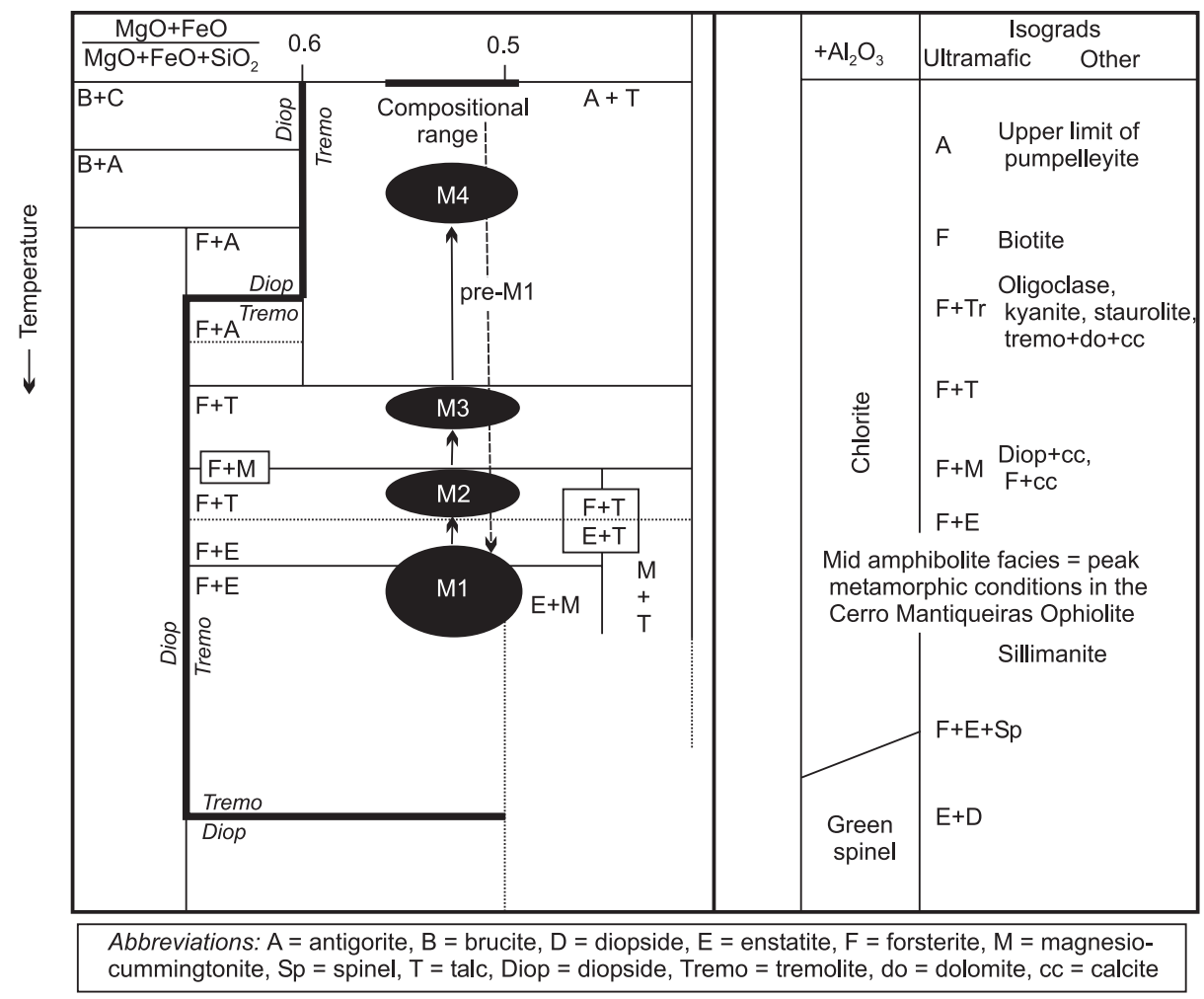

Fig. 8 - Four episodes of metamorphic re-equilibration during the retrograde evolution of the harzburgites from the Cerro Mantiqueiras Ophiolite displayed in the Evans (1977) diagram. A possible previous (pre- $\mathrm{M}_{1}$ ) prograde metamorphic evolution is suggested. Stability field of tremolite to the right of thick black line. Compositional range of Cerro Mantiqueiras Ophiolite harzburgites determined by chemical analyses shown on diagram.

two steps over a 15 -year period, following its initial description by Goñi (1962). Initially, Ricardo Pinheiro Machado and Léo A. Hartmann (1990, unpublished) examined the geology of the ophiolite and country rocks and identified the mid amphibolite facies metamorphism of the harzburgite and the presence of monomineralic blackwall rocks, including albitite. They made some chemical analyses of the minerals in the electron microprobe of the University of São Paulo. They also concluded that the mafic, ultramafic and granitic rocks are in deformational concordance and were submitted to the same mid amphibolite facies event. A preliminary geological map was made at the 1:50,000 scale. Preliminary whole-rock $\mathrm{Rb}-\mathrm{Sr}$ geochronology indicated that the granitic rocks have Neoproterozoic age about $600 \mathrm{Ma}$.

Other investigators in the area (Tommasi et al. 1994) contributed with a significant data base and concluded that the ultramafic sheet is an ophiolite, based on extensive field mapping and microstructural investigations.

The second, detailed and most significant field investigation was made by the authors of this paper in the years 1994 and 1995 as part of the supervision of the doctoral thesis of Jayme A.D. Leite (1997), with considerable financial support from Departamento Nacional da Produção Mineral, Brazilian Government, as part of the $\mathrm{PhD}$ project of JADL at Universidade Federal do Rio Grande do Sul. Because the only topographic sheet available was at the 1:50,000 scale, the ophiolite was surveyed at the 
TABLE VI

Olivine-spinel chemical parameters used for the calculation of equilibrium temperatures with

the Jackson (1969) geothermometer.

\begin{tabular}{c|c|c|c|c|c|c|c|c|c}
\hline Mineral pair & $C r \#$ & $F e^{+3 \#}$ & $A l \#$ & $X_{S p}^{M g}$ & $X_{S p}^{F e}$ & $X_{O l}^{F e}$ & $X_{O l}^{M g}$ & $\ln \mathrm{Kd}_{O l-S p}^{\mathrm{Fe} / \mathrm{Mg}}$ & $T^{\circ} \mathrm{C}$ \\
\hline & 0.61 & 0.31 & 0.08 & 0.20 & 0.80 & 0.10 & 0.90 & 3.58 & 870 \\
1 & 0.63 & 0.31 & 0.06 & 0.21 & 0.79 & 0.10 & 0.90 & 3.52 & 898 \\
3 & 0.63 & 0.30 & 0.06 & 0.22 & 0.78 & 0.10 & 0.90 & 3.46 & 919 \\
4 & 0.65 & 0.29 & 0.06 & 0.17 & 0.83 & 0.10 & 0.90 & 3.78 & 847 \\
\multicolumn{8}{|c|}{ Olivine-Ferro-chromite } \\
5 & 0.45 & 0.50 & 0.05 & 0.16 & 0.84 & 0.12 & 0.88 & 3.65 & 665 \\
6 & 0.48 & 0.46 & 0.06 & 0.16 & 0.84 & 0.08 & 0.92 & 4.10 & 614 \\
7 & 0.42 & 0.50 & 0.08 & 0.13 & 0.87 & 0.13 & 0.87 & 3.80 & 617 \\
8 & 0.44 & 0.46 & 0.10 & 0.10 & 0.90 & 0.13 & 0.87 & 4.09 & 595 \\
9 & 0.46 & 0.51 & 0.03 & 0.16 & 0.84 & 0.09 & 0.91 & 3.97 & 604 \\
10 & 0.44 & 0.53 & 0.03 & 0.18 & 0.82 & 0.09 & 0.91 & 3.82 & 611 \\
11 & 0.43 & 0.51 & 0.06 & 0.12 & 0.88 & 0.13 & 0.87 & 3.89 & 602 \\
12 & 0.41 & 0.56 & 0.03 & 0.18 & 0.82 & 0.09 & 0.91 & 3.82 & 580 \\
13 & 0.42 & 0.55 & 0.04 & 0.13 & 0.87 & 0.09 & 0.91 & 4.21 & 529 \\
14 & 0.38 & 0.60 & 0.02 & 0.17 & 0.83 & 0.09 & 0.91 & 3.89 & 532 \\
15 & 0.40 & 0.59 & 0.01 & 0.15 & 0.85 & 0.09 & 0.91 & 4.04 & 524 \\
16 & 0.42 & 0.49 & 0.09 & 0.05 & 0.95 & 0.09 & 0.91 & 5.25 & 429 \\
17 & 0.35 & 0.65 & 0.00 & 0.14 & 0.86 & 0.09 & 0.91 & 4.12 & 460 \\
18 & 0.42 & 0.54 & 0.04 & 0.05 & 0.95 & 0.09 & 0.91 & 5.25 & 431 \\
\hline
\end{tabular}

1:1,000 scale with the use of a plane table. Rock types and structures were carefully mapped over a two-month period, when rocks were also sampled for laboratory investigations. Several lines were precisely located in the field for gravimetric investigations with a gravimeter from the Universidade Federal do Mato Grosso.

Nearly 400 thin sections were made in the entire investigation period, about 250 for the second leg. A selection of samples was investigated for the chemistry of the minerals. The electron microprobe analyses were made in three laboratories. First, a Cambridge Instruments was used at the Open University, UK, followed by a SEM JEOL 180 at the University of Western Australia and a Cameca SX50 at Universidade Federal do Rio Grande do Sul.
Work in the UK was done by LAH and in Australia and UFRGS by JADL with financial support from the Conselho Nacional do Desenvolvimento Científico e Tecnológico, Brazilian Government. A focussed beam (1-2 $\mu \mathrm{m})$ was used for all chemical analyses and followed standard analytical procedures adopted in the three laboratories, e.g. 20 $\mathrm{kV}$ and $20 \mathrm{nA}$.

\section{APPENDIX 2}

\section{CALCULATION OF OLIVINE-SPINEL EQUILIBRIUM TEMPERATURES}

Temperature estimates for the middle amphibolite metamorphic event $\mathrm{M}_{1}$ are obtained from the olivine-spinel geothermometer (Irvine 1967, Jackson 1969), which is based on the exchange reaction between $\mathrm{Fe}$ and $\mathrm{Mg}$. The requirements for the 


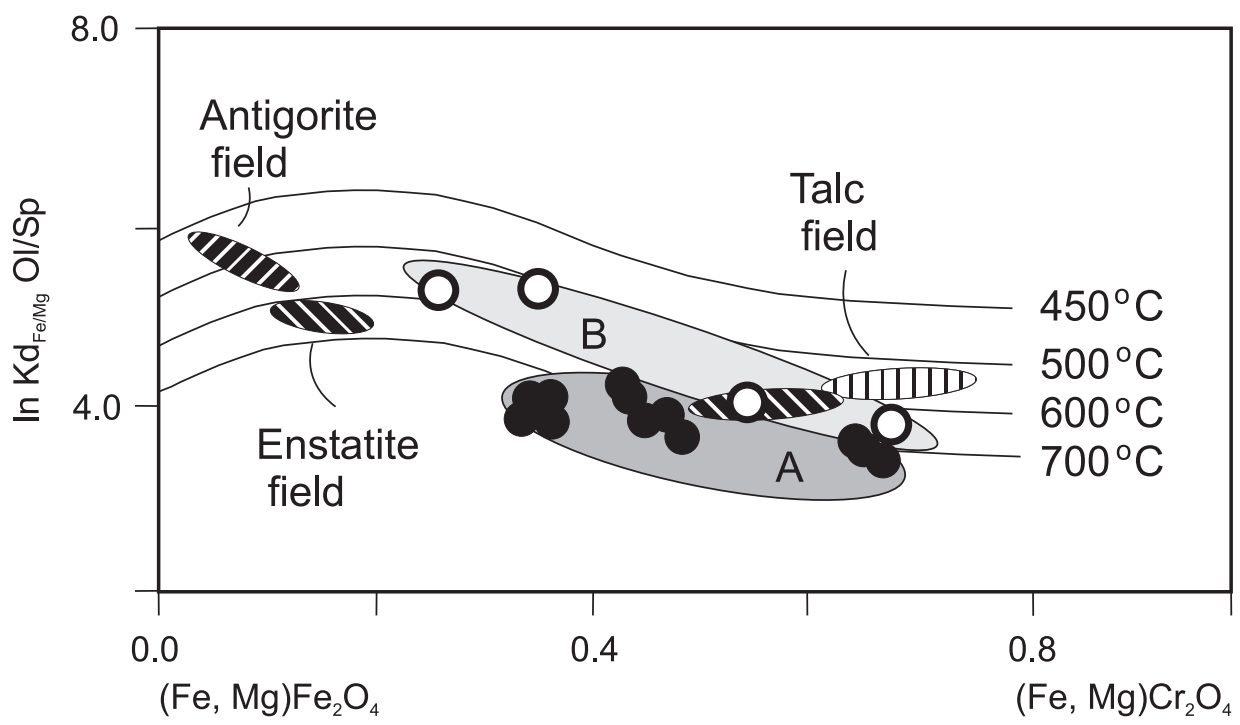

Fig. 9 - Metamorphic conditions in the enstatite, talc and antigorite stability fields prevailing during deformational events in the Cerro Mantiqueiras Ophiolite harzburgites as calculated from olivine Fo90 $\times$ spinel equilibria (Evans and Frost 1975, Sack and Giorso 1991). Plotted Cerro Mantiqueira Ophiolite temperatures reflect compositional groups from the mid amphibolite facies (A) and greenschist facies (B) conditions.

use of this geothermometer are met by the Cerro Mantiqueiras Ophiolite minerals: (1) small variation in $\mathrm{Mg} / \mathrm{Mg}+\mathrm{Fe}$ ratios in olivine around $\mathrm{Fo}_{90}$, and (2) chrome-spinel compositions near the $\left(\mathrm{Fe}^{+2}, \mathrm{Mg}\right)$ $\left(\mathrm{Cr}, \mathrm{Fe}^{+3}\right)_{2} \mathrm{O}_{4}$ face in the spinel compositional prism.

The following equation (Jackson, 1969, p. 63) is used for the temperature $\left({ }^{\circ} \mathrm{C}\right)$ calculation (data from Table VI):

$$
T=\frac{(5580 a+1018 b-1720 c+2400)}{\left(0.9 a+2.56 b-3.08 c-1.47+1.9871 \ln K d_{O l-S p}^{F e / M g}\right)}
$$

In this equation, $a, b$ and $c$ are the fraction of trivalent cations, respectively $\mathrm{Cr}, \mathrm{Al}$ and $\mathrm{Fe} ; a+b+c=$ 1 , and

$K d_{O l-S p}^{F e / M g}=\frac{(M g / M g+F e)_{O l} \times(F e / F e+M g)_{S p}}{(F e / F e+M g)_{O l} \times(M g / M g+F e)_{S p}}$

Although a wide range in temperatures is obtained between $450^{\circ} \mathrm{C}$ and $920^{\circ} \mathrm{C}$, we only make broad generalizations about the temperatures of equilibrium of olivine-spinel pairs in the Cerro Mantiqueiras Ophiolite. This is because Sack and
Ghiorso (1991) observed that the temperatures deduced from the Jackson geothermometer are often too high, particularly in olivine-chrome spinel pairs generated by regional metamorphism of serpentinites, which is the present case. Roeder et al. (1979) also concluded that the Jackson geothermometer yields a large and unreasonable range of temperatures for spinels high in ferric-iron, such as those from the Cerro Mantiqueiras Ophiolite. Nevertheles, the high temperatures $\left(>1000^{\circ} \mathrm{C}\right)$ typical of mantle olivine-spinel pairs were not encountered in the Cerro Mantiqueiras Ophiolite with the Jackson geothermometer.

\section{ACKNOWLEDGMENTS}

The doctoral thesis of JADL at Universidade Federal do Rio Grande do Sul was supported by Conselho Nacional do Desenvolvimento Científico e Tecnológico and Departamento Nacional da Produção Mineral, Brazilian Government. Strong scientific disagreement with the conclusions here presented 
led JADL not to accept co-authorship in the paper. The Electron Microprobe Laboratory at "Centro de Estudos em Petrologia e Geoquímica, Instituto de Geociências, Universidade Federal do Rio Grande do Sul', was acquired with the financial support of PADCT/FINEP; its maintenance has been supported by $\mathrm{CNPq}$ projects.

\section{RESUMO}

O estudo integrado de relações geológicas, micro-estruturais e composição química de minerais resultou na obtenção de informações muito valiosas sobre a evolução dos harzburgitos do Ofiolito Cerro Mantiqueiras, de idade Neoproterozóica. Este importante marcador geotectônico da evolução geológica do extremo sul do Escudo Brasileiro foi serpentinizado de forma muito intensa durante um evento de metamorfismo progressivo, pois a assembléia mineralógica mais antiga observada é olivina + ortopiroxênio + tremolita + chlorita + cromita. Esta assembléia $M_{1}$ foi estabilizada no fácies anfibolito médio - 550- $600^{\circ} \mathrm{C}$, conforme calculado a partir de equilíbrios mineralógicos. Não foram observadas feições mantélicas remanescentes, tanto micro-estruturais (e.g., deformação dúctil de olivina ou cromita) quanto composicionais (e.g., espinélio mantélico). Um evento metamórfico $\mathrm{M}_{2}$ ocorreu no fácies anfibolito inferior ao longo de uma zona de cisalhamento de $100 \mathrm{~m}$ de largura, seguido por intensa serpentinização $\left(\mathrm{M}_{3}\right)$ e formação de estreitas (1-3 m) zonas de cisalhamento $\left(\mathrm{M}_{4}\right)$ contendo asbestos.

Palavras-chave: Química mineral, ofiolito Cerro Mantiqueiras, metamorfismo, Neoproterozóico.

\section{REFERENCES}

Babinski M, Chemale F, Hartmann LA, Van Schmus WR AND SiLva LC. 1996. Juvenile accretion at 750$700 \mathrm{Ma}$ in southern Brazil. Geology 24: 439-442.

Babinski M, Chemale F, Van Schmus WR, HartMANN LA AND Silva LC. 1997. U-Pb and Sm$\mathrm{Nd}$ geochronology of the Neoproterozoic graniticgneissic Dom Feliciano Belt, southern Brazil. Jour S Amer Earth Sci 10: 263-274.

Berhe SM. 1990. Ophiolites in Northeast and East Africa: implications for Proterozoic crustal growth. Jour Geol Soc London 147: 41-57.
Bucher K And Frey M. 2002. Petrogenesis of Metamorphic Rocks. Berlin: Springer-Verlag, 341 p.

CANDia MAF ANd Gaspar JC. 1996. Exsoluções em cromo-espinélios. Rev Bras Geoc 26: 87-92.

Candia MaF, Gaspar JC and Szabó GAJ. 1999. A interação de cromo-espinélio com fases silicáticas nos processos metamórficos. Rev Bras Geoc 29: 633638.

Dick JB AND Bullen T. 1984. Chromian spinel as a petrogenetic indicator in abyssal and alpine-type peridotites and spatially associated lavas. Contrib Mineral Petrol 86: 54-76.

Evans BW. 1977. Metamorphism of alpine peridotite and serpentinite. Annual Rev Earth Planet Sci Lett 5: 397-447.

Evans BW AND Frost BR. 1975. Chrome-spinel in progressive metamorphism: A preliminary analysis. Geoch Cosmoch Acta 39: 959-972.

Evans BW and Trommsdorf V. 1974. On elongate olivine of metamorphic origin. Geology 2: 131-132.

Fernandes LAD, Tommasi A And Porcher CC. 1992. Deformation patterns in the southern Brazilian branch of the Dom Feliciano Belt: a reappraisal. Jour S Amer Earth Sci 5: 77-96.

Fragoso Cesar AR, Lavina EL, Paim PGS and FacCINI UF. 1986. O batólito Pelotas (Proterozóico Superior/ Eo-Paleozóico) no Escudo do Rio Grande do Sul. In: Congresso Brasileiro de Geologia, 34., Goiânia. Proceedings (Anais)..., Goiânia: 1986, p. 1322-1343.

Frantz JC AND Botelho N. 2000. Neoproterozoic granitic magmatism and evolution of the eastern Dom Feliciano Belt in southernmost Brazil: a tectonic model. Gondw Res 3: 7-19.

Gass IG, Lippard SJ And Shelton AW. 1984. Ophiolites and oceanic lithosphere, Oxford: BlackwellScience, 413p.

GoÑ JC. 1962. Origine des roches ultrabasiques et serpentineuses du Précambrien de Rio Grande do Sul (Brésil). Mode de gisement et mineralizations. Bol Esc Geol (UFRGS) 12: 1-33.

Haralyi NLE and Hasui Y. 1982. The gravimetric information and the Archean-Proterozoic structural framework of eastern Brazil. Rev Bras Geoc 12: 160166. 
Hartmann LA. 2002. The Mesoproterozoic Supercontinent Atlantica in the Brazilian Shield - Review of geological and $\mathrm{U}-\mathrm{Pb}$ zircon and $\mathrm{Sm}-\mathrm{Nd}$ isotopic evidence. Gondw Res 5: 157-163.

Hartmann LA and Delgado IM. 2001. Cratons and orogenic belts of the Brazilian Shield and their contained gold deposits. Min Dep 36: 207-217.

Hartmann LA and Remus MVD. 2000. Origem e evolução das rochas ultramáficas do Rio Grande do Sul desde o Arqueano até o Cambriano. In: Holz M AND De Ros LF (Eds.), Geologia do Rio Grande do Sul, Porto Alegre: Ed. CECO/UFRGS, p. 55-78.

Hartmann LA, Leite JAD, McNaughton NJ AND SANTOS JOS. 1999a. Deepest exposed crust of Brazil - SHRIMP establishes three events. Geology 27: 947-950.

Hartmann LA, Nardi LVS, Formoso MLL, Remus MVD, Lima EF And Mexias AS. 1999b. Magmatism and metallogeny in the crustal evolution of Rio Grande do Sul Shield, Brazil. Pesquisas (UFRGS) 26: 45-63.

Hartmann LA, Leite JAD, Silva LC, Remus MVD, McNaughton NJ, Groves DI, Fletcher IR, SANTOS JOS AND VASCONCEllos MAZ. 2000a. Advances in SHRIMP geochronology and their impact on understanding the tectonic and metallogenic evolution of southern Brazil. Australian Jour Earth Sci 47: 829-844.

Hartmann LA, Porcher CC And Remus MVD. 2000b. Evolução das rochas metamórficas do Rio Grande do Sul. In: Holz M ANd De Ros LF (Eds.) Geologia do Rio Grande do Sul. Ed. CECO/UFRGS: 79-118.

IRviNe TN. 1967. Chromian spinel as a petrogenetic indicator. Part 2: petrological application. Can Jour Earth Sci 4: 71-103.

JACKSON ED. 1969. Chemical variation in coexisting chromite and olivine in chromitite zones of the Stillwater Complex. Econ Geol Mon 4: 41-71.

Jost H And Hartmann LA. 1984. Província Mantiqueira - Setor Meridional. In: AlmeIDA FFM AND Hasui Y (Eds.), O Pré-Cambriano do Brasil, São Paulo: Edgard Blücher, p. 345-368.

Kimball KL. 1990. Effect of hydrothermal alteration on the compositions of chromian spinels. Contrib Mineral Petrol 105: 337-346.
LEITE JAD. 1997. A origem dos harzburgitos da Sequência Cerro Mantiqueiras e implicações petrotectônicas para o desenvolvimento do Neoproterozóico da porção oeste do Escudo Sul-riograndense. PhD thesis, Universidade Federal do Rio Grande do Sul, Porto Alegre, 224 p. (unpublished).

Leite JAD, Hartmann LA, McNaughton NJ AND Chemale F. 1998. SHRIMP U/Pb zircon geochronology of Neoproterozoic juvenile and crustalreworked terranes in southernmost Brazil. Internat Geol Rev 40: 688-705.

Lima EF AND NARDi LVS. 1998. The Lavras do Sul Shoshonitic Association: implications for the origin and evolution of Neoproterozoic shoshonitic magmatism in southernmost Brazil. Jour S Amer Earth Sci 11: $67-77$.

Machado N, Koppe JC and Hartmann LA. 1987. A Late Proterozoic U-Pb age for the Bossoroca Belt, Rio Grande do Sul Brazil. Jour S Am Earth Sci 3(2/3): 87-90.

Pimentel MM And Fuck RA. 1992. Neoproterozoic Crustal Accretion in central Brazil. Geology 20: 375379.

Porcher CA And Lopes RC. (Orgs.) 2000. Programa levantamentos geológicos básicos do Brasil: Cachoeira do Sul, folha SH.22-Y-A do Estado do Rio Grande do Sul, Brasília: CPRM, 131 p. + maps at $1: 250,000$ scale.

Power Mr, Pirrie D, Andersen JCO And Wheeler PD. 2000. Testing the validity of chrome spinel chemistry as a provenance and petrogenetic indicator. Geology 28: 1027-1030.

Ramgrab GE, Wildner W and Camozzato E. (Orgs.) 1997. Programa levantamentos geológicos básicos do Brasil, Porto Alegre: folha SH.22-Y-B do Estado do Rio Grande do Sul. Brasília: CPRM, 140 p. + maps at 1:250,000 scale.

Remus MVD, Hartmann LA, McNaughton NJ, Groves KI AND Fletcher IR. 2000. The link between hydrothermal epigenetic copper mineralization and the Caçapava Granite of the Brasiliano Cycle in southern Brazil. Jour S Amer Earth Sci 13: 191216.

Roeder PL, Campbell IH and Jamieson HE. 1979. A Re-evaluation of the olivine-spinel geothermometer. Contrib Mineral Petrol 68: 325-334. 
SACK RO AND GHIORso MS. 1991. Chromian spinels as petrogenetic indicators: Thermodynamics and petrological applications. Am Mineral 76: 827-847.

SAdowski GR And Bettencourt JS. 1996. Mesoproterozoic tectonic correlation between eastern Laurentian and western Amazon Craton. Prec Res 76: 213227.

STERN RJ. 1994. Arc assembly and continental collision in the Neoproterozoic East African Orogen: Implications for the consolidation of Gondwanaland. Ann Rev Earth Planet Sci 22: 319-351.
Suita MTF ANd Strieder A. 1996. Cr-spinels from Brazilian mafic-ultramafic complexes: metamorphic modifications. Intern Geol Rev 38: 245-267.

Tommasi A, Fernandes LAD, Pinheiro Machado R, Kraemer R AND Koester E. 1994. Incorporação de lascas do manto à crosta continental nas porções externas do Cinturão Dom Feliciano - evidências de uma zona de cisalhamento litosférica. Pesquisas (Porto Alegre) 21: 79-84.

VAnCE JA AND Dungan MA. 1977. Formation of peridotites by deserpentinization in the Darrington and Sultan areas, Cascade Mountains, Washington. Geol Soc Am 88: 1497-1508. 